\title{
Relationship of Self-Compassion with Anxiety and Depressive Symptoms in Infertile Women
}

\author{
Elif Ganime Aygünn ${ }^{1}$ (D) , BarışSancak² (iD , Ürün Özer Ağırbaş ${ }^{3}$ (iD
}

${ }^{1}$ Acibadem Mehmet Ali Aydinlar University Atakent Hospital, Department of Obstetrics and Gynaecology, Istanbul, Turkey

${ }^{2}$ Acibadem Mehmet Ali Aydinlar University Atakent Hospital, Department of Psychiatry, Istanbul, Turkey

${ }^{3}$ Acibadem Mehmet Ali Aydinlar University, School of Medicine, Department of Psychiatry, Istanbul, Turkey

Elif Ganime AYGÜN

Barış SANCAK

Ürün ÖZER AĞIRBAŞ

Correspondence: Elif Ganime Aygün Acibadem Mehmet Ali Aydinlar University Atakent Hospital, Department of Obstetrics and Gynaecology, Istanbul, Turkey

Phone: +902124044117

E-mail: elif.aygun@acibadem.com

\begin{abstract}
Purpose: Infertile women have a higher rate of psychiatric symptoms compared to fertile women while depression and anxiety are among the most common psychiatric disorders in this group. Self-compassion might be a variable in predicting depression, anxiety and stress. The study aimed to evaluate self-compassion in infertile women and to examine its relationship with depression and anxiety levels.
\end{abstract}

Methods: This cross-sectional study included a total number of 122 participants. The study group $(n=50)$ consisted of women who applied to the gynaecology and obstetrics clinic for infertility treatment and were recruited consecutively. The control group ( $\mathrm{n}=72$ ) was recruited from hospital staff and their relatives, of the similar age and gender as the study group. The participants filled Self-Compassion Scale (SCS) and Hospital Anxiety and Depression Scale (HADS) in addition to sociodemographic data form.

Results: SCS scores were significantly lower, and HADS scores (both depression and anxiety) were significantly higher in the study group, compared to the control group. There was a negative correlation between SCS and HADS scores ( $p<$ 0.001), indicating that lower self-compassion levels are associated with increased depression and anxiety. Duration of infertility treatment was not correlated with SCS and HADS scores ( $p>0.05)$.

Conclusion: Infertile women have higher levels of depression and anxiety while self-compassion is an influential factor in maintaining psychological well-being and preventing anxiety and depressive symptoms in this group. Self-compassion based or other interventions targeting psychological well-being of infertile women would be beneficial.

Keywords: Anxiety; Self-Compassion; Depression; Female; Infertility; Psychological Factors

\section{İnfertil Kadınlarda Özşefkat ile Anksiyete ve Depresif Belirtiler Arasındaki Illişki}

ÖZET

Amaç: Infertil kadınlarda fertil kadınlara göre psikiyatrik belirti gözlenme oranı daha fazladır ve depresyon ile anksiyete bu gruptaki en yaygın psikiyatrik rahatsızılılardandır. Özşefkat; depresyon, anksiyete ve stresi öngörmekte değerli bir değişken olabilmektedir. Çalışmamız infertil kadınlarda özşefkati değerlendirmeyi ve depresyon ve anksiyete düzeyleri ile ilişkisini incelemeyi amaçlamaktadır.

Yöntem: Bu kesitsel araşı̧ımanın örneklemi 122 hastadan oluşmaktadır. İnfertilite tedavisi için kadın hastalıkları ve doğum kliniğine başvuran kadınlar ardışı olarak çalışma grubuna $(N=50)$ dahil edilmiştir. Kontrol grubu $(N=72)$ ise hastane çalışanları ve akrabalarından, benzer yaş ve cinsiyet gözetilerek seçilmiştir. Katılımcılar sosyodemografik veri formuna ek olarak Öz-Anlayış Ölçeği (SCS) ve Hastane Anksiyete ve Depresyon Ölçeği (HADS) formlarını doldurmuşlardır.

Bulgular: Kontrol grubu ile karşılaştıııldığında, çalışma grubunda SCS skorları anlamlı olarak düşük ve HADS skoru (depresyon ve anksiyete) anlamlı olarak yüksek bulunmuştur. SCS ve HADS skorları arasında negatif korelasyon tespit edilmiştir $(p<0.001)$. Bu ilişki, düşük özşefkatın yüksek depresyon ve anksiyete ile bağlantılı olduğunu göstermektedir. İnfertilite tedavisinin süresi SCS ve HADS skorları ile bağlantısız bulunmuştur ( $p>0.05)$.

Sonuç: İnfertil kadınlarda depresyon ve anksiyete düzeyleri daha yüksek saptanmakta olup, özşefkat bu grupta psikolojik sağlığın korunması ile anksiyete ve depresif belirtilerin önlenmesinde etkili bir faktördür. İnfertil kadınların psikolojik iyi oluşlarını hedefleyen özşefkat temelli ya da diğer girişimler yararlı olacaktır.

Anahtar Sözcükler: Anksiyete; Özşefkat; Depresyon; Kadın; İnfertilite; Psikolojik faktörler 
nfertility is defined as failure of conception after one year of unprotected intercourse in the fertile phase of the menstrual cycles and it is estimated that impaired fertility affects $10-15 \%$ of couples (1). Eventually, advances in medicine have opened up the possibility of diagnosis and treatment in many cases of infertility, as well as the use of assisted reproductive techniques enabling conception in many couples (2).

Infertility, which is generally considered as a stressful period for the couple, is particularly accepted as a devastating experience for women $(3,4)$. The prevalence of psychiatric disorders was found to be higher in infertile women compared to fertile women $(5,6)$. In women who applied to assisted reproductive treatment, the rate of psychiatric disorders was determined as high as $40.2 \%$ (7). Depressive symptoms and anxiety are among the predominant psychiatric symptoms in infertile women $(2,7$, 8,9 ). Studies revealed that the prevalence of major depression and anxiety disorder in this group was as high as $17.0 \%$, and $28.6 \%$, respectively $(7,9)$.

The term self-compassion, developed by Neff (10), signifies being open to one's own suffering along with a kind and caring approach toward oneself. It involves an understanding, nonjudgmental attitude toward one's pain, inadequacies and failures, and recognizing it as a part of the common human experience. Self-compassion stands out as a positive factor in terms of coping, life satisfaction and psychological well-being. It has been suggested that people with high self-compassion levels have lower levels of depression and anxiety when faced with a stressor (11). In a limited number of studies in the literature focusing on self-compassion in infertile women, self-compassion has been reported as a protective factor in terms of fertility-related distress (12). It is found to be associated with subjective well-being, hope and decreased social stigma in infertile women $(4,13)$. Self-compassion comes to the fore in predicting depression, anxiety, and stress among women with infertility (14), certainly creating the need for further research in this area.

\section{MATERIALS AND METHODS}

The study was conducted in Acıbadem University Atakent Hospital in a 2-month period.

Ethics committee approval (approval number 202119/01) was obtained from the same institution for the study. The study group consisted of women who applied to Gynecology and Obstetrics outpatient clinic with the complaint of infertility for treatment purposes. Fifty consecutive patients who agreed to participate in the study and filled out the study forms and scales completely were included in the study. Exclusion criteria for the study group were illiteracy and the presence of severe psychiatric disorders such as psychotic disorders or mental retardation. Simultaneously, it was aimed to reach a similar number of participants for the control group, consisting of hospital staff and their relatives. The people who participated in the study via googleforms in the same time period were included in the control group. According to the answers given to the questions in the study form, people who have received or are still receiving infertility treatment were subsequently excluded from the control group.

The questions were given to the study group in print. For the control group, the questions were prepared via googleforms and sent by sharing the link via text message. The printed forms begin with the Informed Consent Form giving information about the study. The survey in googleforms also starts with the Informed Consent Form and the question of confirming participation in the study, and it is not possible for the participants who do not give consent to proceed. After the Informed Consent Form, Sociodemographic Form, Self-Compassion Scale, Hospital Anxiety and Depression Scale were used during data collection.

\section{Sociodemographic Form}

It is a short form consisting of questions about the sociodemographic characteristics as well as the past infertility treatment. It was developed by the researchers in line with the purpose of the study.

\section{Self-Compassion Scale (SCS)}

The scale was developed by Neff (10) to measure individuals' self-compassion level. The Turkish validity and reliability study was conducted by Deniz et al. (15). The Likert-type self-rating scale, which originally consisted of 26 items and each item was scored between 1 and 5, was adapted into Turkish as 24 items. Higher scores of the scale indicate higher self-compassion levels.

\section{Hospital Anxiety and Depression Scale (HADS)}

The scale aims to measure the anxiety and depression levels of the participants. The Turkish validity and reliability study of the scale was performed by Aydemir et al. (16). The self-rating scale consists of a total of 14 items and 2 subscales, 7 of the items question symptoms of anxiety 
and 7 of them question symptoms of depression. Higher scores indicate higher levels of anxiety and depression.

\section{Data Analysis}

All the data obtained in the study was analyzed using the SPSS 21.0 package program (SPSS Inc., Chicago IL, USA). Skewness and kurtosis indices, histogram graph, QQ plot graph, and Kolmogorov-Smirnov normality test were used to determine whether the variables showed a normal distribution. Descriptive statistics were used to determine the participants' characteristics. An independent t-test was used to examine the self-compassion, HADS anxiety, and HADS depression scores between groups. The correlations between the normally distributed scale scores were analyzed by Pearson analysis. Spearman analysis was applied to correlate the scales with the duration of infertility treatment, which is non-normally distributed. In addition, a Multiple Linear Regression Analysis was applied to show the mediating effect of total self-compassion score. A $p \leq$ 0.05 was considered statistically significant.

In the post hoc power analysis, the effect size was found to be 0.411 and the power analysis of the study was 0.613 in terms of the results of SCS scores between two groups.

\section{RESULTS}

The study group consisted of 50 women who applied to the gynaecology and obstetrics clinic for infertility treatment and were recruited consecutively. In the control group, 10 of the 87 participants were excluded from the study because they had received infertility treatment in the past, and 5 participants were excluded because they filled the forms incompletely. The mean age of the study group was 31.50 ( $n=50$, sd. 5.104), while the mean age of the control group was 31.86 ( $n=72, s d .7 .681)$. There was no significant difference between the groups in terms of age. Considering the education levels, 18 (36\%) of the study group were primary school graduates, $23(46 \%)$ were high school graduates, and $9(18 \%)$ were university graduates. In the control group, 11 were high school (15.3\%) and 61 (84.7) were university graduates. There were 28 (38.9\%) participants in the control group who had children with the mean number of children 0.54 (sd. 0.768). The mean duration of infertility treatment in the study group was 5.48 months (sd. 5.023). Six (12\%) participants in the study group had a history of unsuccessful infertility treatment in the past.

The independent samples t-test was used to compare the infertility treatment group with the control group in terms of SCS and HADS scores. Self-compassion scores were significantly lower and depression and anxiety scores were significantly higher in the study group, compared to control group. The details of the comparison are given in Table 1.

\begin{tabular}{|c|c|c|c|c|c|}
\hline & $\begin{array}{l}\text { Study } \\
\text { Group } \\
(n=50)\end{array}$ & $\begin{array}{l}\text { Control } \\
\text { Group } \\
(n=72)\end{array}$ & $t$ & df & $p$ \\
\hline $\begin{array}{c}\text { Self- } \\
\text { Compassion } \\
\text { Scale }\end{array}$ & $\begin{array}{c}71.12 \\
\text { (sd.17.779) }\end{array}$ & $\begin{array}{c}78.708 \\
\text { (sd.19.273) }\end{array}$ & 2.207 & 120 & .029 \\
\hline $\begin{array}{l}\text { HADS } \\
\text { Anxiety }\end{array}$ & $\begin{array}{c}9.36 \\
\text { (sd. 5.363) }\end{array}$ & $\begin{array}{c}7.319 \\
\text { (sd. } 4.424)\end{array}$ & 2.295 & 120 & .023 \\
\hline $\begin{array}{c}\text { HADS } \\
\text { Depression }\end{array}$ & $\begin{array}{c}6.80 \\
\text { (sd. } 5.387 \text { ) }\end{array}$ & $\begin{array}{c}5.041 \\
\text { (sd. 3.694) }\end{array}$ & 2.14 & 120 & .034 \\
\hline
\end{tabular}

Student t-test, sd=standart deviation, df: degrees of freedom, $\mathrm{t}: \mathrm{t}$ value.

The correlations between the scales were analyzed by Pearson correlation analysis, it was found that there is a negative correlation between SCS and HADS depression and anxiety scores (Pearson correlation coefficient 0.727 and 0.656 , respectively, $\mathrm{p}<0.001)$. In addition, HADS depression and anxiety scores show a positive correlation with each other (Pearson correlation coefficient 0.848 , $p<0.001)$. Spearman correlation analysis was applied to examine the correlation between the duration of infertility treatment (in months) and the scale scores and this variable did not show a significant correlation with selfcompassion, anxiety, and depression scores ( $p>0.05)$.

We applied linear regression analysis to test our hypothesis that self-compassion has a mediating effect on depression and anxiety in women undergoing infertility treatment. Because HADS anxiety and depression scores showed a high correlation with each other, they were combined and included in the analysis as a single score. The result of the linear regression analysis is shown in Table 2. As a result of multiple linear regression analysis, the decrease in self-compassion total score and infertility and/or receiving infertility treatment explained $52.3 \%$ of the increase in HADS scores. It is seen that a significant part of this effect comes from the self-compassion score. As shown in Table 1, it was found that infertility/receiving infertility treatment led to a significant increase in HADS scores. As a result of our multiple linear regression analysis, it is seen that this effect occurs as a result of the mediator effect of self-compassion scores. 


\begin{tabular}{l} 
Table 2. The effect of self-compassion total score and infertility treatment on HADS scores: Multiple Regression Analysis \\
\hline \\
\hline
\end{tabular}

\section{DISCUSSION}

Psychological factors associated with infertility have been the subject of many studies, still whether stress and infertility are related as cause or consequence is controversial (3). Some authors have suggested that psychological factors may play a role in the emergence of infertility. It has been suggested that high anxiety levels have a negative effect on conception rates $(17,18)$. However, psychological problems arised as a consequence of infertility have come to the fore more.

Although infertility is considered a stressful period for spouses, it is underlined that it is challenging especially for women $(3,4)$. One of the the factors that affect the higher level of stress is the limitation brought by the reproductive age of women (19). In addition, the social stigmatization of women by being held responsible for infertility, as well as the fact that having a child plays a crucial role in women's identity and status in social life in some societies, contributes the stress level of women $(2,4)$. The emergence marital dissatisfaction in infertility and considering having children as a source of maintaning the foundation of the family may also increase the pressure on women (4).

While assisted reproductive techniques such as IVF help infertile couples to obtain conception, the treatment process is especially challenging for women due to reasons such as hormonal changes and medical interventions faced by women during this course. Uncertainity is a significant stressor as well as the fear of treatment failure and inability to conceive $(19,20,21)$.

Psychological distress is common in infertile women, even many women report the evaluation and treatment of infertility as the most upsetting experience of their lives (2). Psychiatric symptoms and disorders were reported more in infertile women compared to fertile women or general population $(5,6,7)$. Noorbala et al. (5) found that $44 \%$ of infertile women had a psychiatric disorder, this rate is significantly higher compared to fertile women (28.7\%). Anxiety and depressive symptoms are among the most investigated symptoms and were found at higher rates in infertile women in many studies $(7,21)$. It has been underlined that individuals receiving assisted reproductive therapy are particularly at risk for psychiatric disorders. The rate of psychiatric disorders in women applying for assisted reproductive treatment has been reported as high as $40.2 \%(7,9)$. Anxiety and depressive disorders are among the most prevalent disorders in this group (9). Major depressive disorder was reported in 39\% of women receiving infertility treatment (22). Among women preparing for assisted reproduction treatment, $26.8 \%$ found to have depressive disorders and $28.6 \%$, anxiety disorders (7). In an another study, women who applied to infertility clinics, were exibiting significant symptoms of depression $(56 \%)$ and anxiety (76\%) (23).

In our study, depression and anxiety levels determined by HADS were found to be significantly higher in infertile women compared to the control group. This finding is consistent with similar studies using rating scales and self-administered questionnaires. In fact, the HADS scale averages in our study (depression score $6.8 \pm 5.3$, anxiety score $9.3 \pm 5.3$ ) were found to be higher compared to similar studies. In a study using HADS in infertile women, mean depression score was $4.6 \pm 3.1$, mean anxiety score was $6.7 \pm 3.5$ (7). In another study, the HADS depression score was $4.6 \pm 2.9$ and the anxiety score was $6.9 \pm 3.1$ (21).

The duration of infertility has been reported as a factor that increases the stress level in infertile women (19). There are studies reporting that the length of the treatment period also increases emotional stress (24). On the contrary, there are studies reporting that previous assisted reproductive treatments do not affect depression and anxiety levels (7). In our study, the duration of infertility treatment and unsuccessful treatment attempts in the 
past were not found to be associated with anxiety and depressive symptoms or self compassion levels.

Compassion may be described as being aware and sensitive to others' suffering with the desire to alleviate it and self-compassion may be explained simply as compassion directed inward. The three main elements of selfcompassion are self-kindness (versus self-judgement), a sense of common humanity (versus self-isolation), and mindfulness (versus overidentification) (25). It is suggested that self-compassion provides emotional resilience when faced with difficult life experiences such as grief, sadness, burnout and failure. Increased self-compassion was found to be associated with decrease in shame and guilt and improvement in interpersonal relationships (15, 25). Self-compassion stands out as a positive factor in terms of coping, life satisfaction and psychological wellbeing. It has been suggested that people with high selfcompassion levels have lower levels of depression and anxiety when faced with a stresful life event (11).

It has been reported that infertile individuals, especially women, tend to exibit more self-judgment and less self-compassion (26). The association between selfcompassion and infertility-related distress is consistent in the literature $(4,13,26)$. Further, lower self-compassion levels were found to be associated with depression and anxiety in infertile women (14). In our study, self-compassion levels were found to be significantly lower in the study group compared to the control group. In addition, lower self-compassion levels were found to be related with anxiety and depressive symptoms in this group. Such findings reveal that self-compassion is an important variable in associated with psychological symptoms in infertile women.

Women may hide their distress from health providers because they are self-conscious, afraid of being criticized, or stigmatized. Also they may not perceive the need for counseling (2). Many clinicians conducting infertility treatment rarely require consultation with a counselor before or during fertility treatment, and special issues such as multiple miscarriages, which may require psychological support are often not adequately addressed (27). These can prevent infertile women from getting the psychosocial support they need.

It has been reported in the literature that psychological interventions can reduce distress associated with infertility (2). A comprehensive review concluded that psychotherapy (either group psychotherapy or individual/couple psychotherapy) caused a decrease in anxiety and depressive symptoms in infertile individuals (28). A study investigating the effectiveness of counseling during the IVF process, revealed that the couples receiving counseling had significantly lower anxiety and depression scores, higher life satisfaction and higher pregnancy rates compared to the controls (29). Mind-body programs targeting infertile couples including relaxation techniques, stress management, coping-skills training and group support have also been found beneficial (30). Self-compassion could be an important variable for the management of infertility-related psychological symptoms. Hence, improvement in psychological well-being was observed in infertile women who received self-compassion training (4).

To the best of our knowledge, our study is the first in Turkey to investigate self-compassion levels in infertile women and to evaluate self-compassion as a mediator in terms of anxiety and depressive symptoms in this group. Our study has some limitations such as: Since it is carried out in a single center, it is not sufficient to generalize the results. The use of self-rating scales causes participants to report their symptoms subjectively. The absence of a structured psychiatric interview does not allow for a definitive diagnosis.

In infertility, the role of the physician is crucial, not only carrying out the diagnosis and treatment process in the best way, but also providing and supporting the mental well-being of the infertile woman. In this respect, it is important to screen this group for psychological symptoms, especially anxiety and depression. Patients who experience anxiety and/or depressive symptoms should be referred to a mental health professional. Interventions that will increase the psychological well-being of infertile women are fundamental. Self-compassion stands out as an effective factor in maintaining psychological wellbeing and preventing anxiety and depressive symptoms in infertile women. Accordingly, practices to increase selfcompassion will be beneficial, as well as further research in this area.

\section{DECLARATIONS}

Disclaimers: The views expressed in the submitted article are authors' own and not an official position of the institution's or funder's.

Source(s) of support: The authors did not receive any grants, equipment, drugs, and/or other support that facilitated conduct of the work described in the article or for the writing of the article itself. 
Ethics Approval: This study was approved by the Acibadem Mehmet Ali Aydinlar University Research Ethics Committee (ATADEK) on 30/09/2021 with the decision number 2021/19.

Author Contributions: Elif Ganime Aygun: Conceptualization, Data curation, Investigation, Project administration, Resources, Writing - original draft, Writing - review \& editing. Barış Sancak: Formal Analysis, Project administration, Validation, Writing - review \& editing. Ürün Özer Ağırbaş: Conceptualization, Data curation, Investigation, Methodology, Project administration, Supervision, Validation, Writing - original draft, Writing review \& editing.

Data Availability: Derived data supporting the findings of this study are available from the corresponding author upon reasonable request.

Disclosure of Relationships and Activities: The authors declare no conflict of interest to disclose.

\section{REFERENCES}

1. Evers JL. Female subfertility. Lancet. 2002;360:151-9. DOI: 10.1016/ S0140-6736(02)09417-5.

2. Cousineau TM, Domar AD. Psychological impact of infertility. Best Pract Res Clin Obstet Gynaecol. 2007;21:293-308. DOI: 10.1016/j. bpobgyn.2006.12.003.

3. Greil AL. Infertility and psychological distress: a critical review of the literature. Soc Sci Med. 1997;45:1679-704. DOI: 10.1016/ s0277-9536(97)00102-0.

4. Alireza Afshani S, Abooei A, Mohamad Abdoli A. Self-compassion training and psychological well-being of infertile female. Int J Reprod Biomed. 2019;17:757-62. DOI: 10.18502/ijrm.v17i10.5300.

5. Noorbala AA, Ramezanzadeh F, Abedinia N, et al. Psychiatric disorders among infertile and fertile women. Soc Psychiatry Psychiatr Epidemiol. 2009;44:587-91. DOI: 10.1007/s00127-008-0467-1.

6. Sbaragli C, Morgante G, Goracci A, et al. Infertility and psychiatric morbidity. Fertil Steril. 2008;90:2107-11. DOI: 10.1016/j. fertnstert.2007.10.045

7. Chen TH, Chang SP, Tsai CF, et al. Prevalence of depressive and anxiety disorders in an assisted reproductive technique clinic. Hum Reprod. 2004;19:2313-8. DOI: 10.1093/humrep/deh414.

8. Domar AD, Broome A, Zuttermeister PC, et al. The prevalence and predictability of depression in infertile women. Fertil Steril. 1992;58:1158-63. PMID: 1459266.

9. Volgsten H, Skoog Svanberg A, Ekselius L, et al. Prevalence of psychiatric disorders in infertile women and men undergoing in vitro fertilization treatment. Hum Reprod. 2008;23:2056-63. DOI: 10.1093/humrep/den154.

10. Neff KD. The development and validation of a scale to measure self-compassion. Self and Identity 2003; 2:223-50. DOI: $10.1080 / 15298860309027$.

11. Allen $A B$, Leary MR. Self-Compassion, stress, and coping. Soc Personal Psychol Compass. 2010;4:107-18. DOl: 10.1111/j.1751-9004.2009.00246.x.
12. Galhardo A, Cunha M, Pinto-Gouveia J. Mindfulness-Based program for infertility: efficacy study. Fertil Steril. 2013;100:1059-67. DOI: 10.1016/j.fertnstert.2013.05.036

13. Raque-Bogdan TL, Hoffman MA. The relationship among infertility, self-compassion, and well-being for women with primary or secondary infertility. Psychology of Women Quarterly 2015;39:48496. DOI: 10.1177/0361684315576208.

14. Sadiq U, Rana F, Munir M. Marital quality, self-compassion and psychological distress in women with primary infertility. Sex and Disabil. 2021;1-11. DOI: 10.1007/s11195-021-09708-w.

15. Deniz ME, Kesici ş, Sümer AS. The validity and reliability study of the Turkish version of self-compassion scale. Soc Behav Pers. 2008;36:1151-60. DOI: 10.2224/sbp.2008.36.9.1151.

16. Aydemir Ö, Güvenir T, Kuey L, et al. Validity and reliability of Turkish version of Hospital Anxiety and Depression Scale. Turk Psikiyatri Derg. 1997;8:280-7.

17. Harrison RF, O'Moore RR, O'Moore AM. Stress and fertility: some modalities of investigation and treatment in couples with unexplained infertility in Dublin. Int J Fertil. 1986;31:153-9. PMID: 2875038.

18. Edelman RJ, Golombok S. Stress and reproductive failure. J Reprod Infant Psychol. 1989;7:79-86. DOI: 10.1080/02646838908403578.

19. Wiweko B, Anggraheni U, Elvira SD, et al. Distribution of stress level among infertility patients. Middle East Fertil Soc J. 2017;22:145-8. DOI: 10.1016/j.mefs.2017.01.005.

20. Massarotti C, Gentile G, Ferreccio C, et al. Impact of infertility and infertility treatments on quality of life and levels of anxiety and depression in women undergoing in vitro fertilization. Gynecol Endocrinol. 2019;35:485-9. DOI: 10.1080/09513590.2018.1540575.

21. Matsubayashi $H$, Hosaka $T$, Izumi $S$, et al. Emotional distress of infertile women in Japan. Hum Reprod. 2001;16:966-9. DOI: 10.1093/ humrep/16.5.966.

22. Holley SR, Pasch LA, Bleil ME, et al. Prevalence and predictors of major depressive disorder for fertility treatment patients and their partners. Fertil Steril. 2015;103:1332-9. DOI: 10.1016/j.fertnstert.2015.02.018.

23. Pasch LA, Holley SR, Bleil ME, et al. Addressing the needs of fertility treatment patients and their partners: are they informed of and do they receive mental health services? Fertil Steril. 2016;106:209-15. e2. DOI: 10.1016/j.fertnstert.2016.03.006.

24. Chiba H, Mori E, Morioka Y, et al. Stress of female infertility: relations to length of treatment. Gynecol Obstet Invest. 1997;43:171-7. DOI: $10.1159 / 000291848$.

25. Germer CK, Neff KD. Self-compassion in clinical practice. J Clin Psychol. 2013;69:856-67. DOI: 10.1002/jclp.22021.

26. Cunha M, Galhardo A, Pinto-Gouveia J. Experiential avoidance, self-compassion, self-judgment and coping styles in infertility. Sex Reprod Healthc. 2016;10:41-7. DOI: 10.1016/j.srhc.2016.04.001.

27. Domar AD, Seibel MM. (1990). Emotional aspects of infertility. In MM Seibel (Ed.), Infertility: A comprehensive text. Appleton \& Lange; 1990. pp. 23-35.

28. de Liz TM, Strauss B. Differential efficacy of group and individual/ couple psychotherapy with infertile patients. Hum Reprod. 2005;20:1324-32. DOI: 10.1093/humrep/deh743.

29. Terzioglu F. Investigation into effectiveness of counseling on assisted reproductive techniques in Turkey. J Psychosom Obstet Gynaecol. 2001;22:133-41. DOI: 10.3109/01674820109049965.

30. Domar AD, Seibel MM, Benson $H$. The mind/body program for infertility: a new behavioral treatment approach for women with infertility. Fertil Steril. 1990;53:246-9. DOI: 10.1016/ s0015-0282(16)53275-0. 